\title{
Przemiany na rynku cebuli w latach 1995-2012
}

\section{Wstęp}

Cebula to ważne warzywo pod względem wielkości produkcji, tak w kraju, jak i na świecie. Powierzchnia zasiewów cebuli w latach 2010-2012 zajmowała 7,5\% ogólnej powierzchni upraw warzyw. Ustępowała jedynie pomidorom, których udział stanowił 8,3\%. Pod względem zbiorów cebula z udziałem 7,6\% znajdowała się na trzecim miejscu po pomidorach i arbuzach. Warzywa odgrywają również istotną rolę w międzynarodowej wymianie handlowej. W latach 2010-2012 średnio 8,6\% produkcji podlegało wymianie międzynarodowej. W całym eksporcie większe są tylko obroty pomidorami.

\section{Cel, zakres i metody badań}

Celem badań było określenie zmian w produkcji oraz handlu cebulą na świecie oraz w Polsce. Do realizacji celu posłużono się metodą opisową oraz analizą literatury. W celu prezentacji wyników zastosowano zestawienia tabelaryczne oraz wykresy. Znaczący udział cebuli zarówno w produkcji, jak i handlu warzywami na świecie oraz w Polsce uzasadnia podjęcie tematu.

Analiza obejmuje lata 1995-2012. Wybór takiego okresu u podyktowany był dostępnością danych pierwotnych. W celu uniknięcia wahań nieregularnych podzielono okres na równe trzyletnie podokresy. Zmiany w czasie badano za pomocą indeksów o stałej podstawie, którą była średnia wartość z lat 1995-1997, a strukturę - wykorzystując wskaźniki procentowe. 


\section{Produkcja i handel światowy}

Na produkcję światową warzyw gruntowych wpływ ma wielkość zasiewów oraz wydajność, czyli plonowanie. Wydajność zależna jest od czynników środowiskowych, na które człowiek ma ograniczony wpływ, oraz od technologii produkcji. Główne czynniki środowiskowe to jakość gleby oraz zasobność w wodę. Technologia zależy natomiast od człowieka i wynika z kombinacji nakładów pracy i kapitału. Intensywność jest zróżnicowana w skali świata i wynika z lokalnych albo regionalnych uwarunkowań. Wpływa to na zróżnicowanie produkcji objawiające się odmienną wydajnością.

Zbiory cebuli wzrosły w stosunku do lat 1995-1997 dwukrotnie, do średnio 82 mln ton w latach 2010-2012 (rys. 1). Średnie plony światowe zwiększyły się w tym okresie ze $170 \mathrm{do} 194 \mathrm{dt} / \mathrm{ha}$ (14\%), a powierzchnia o 74\% - do 4,2 mln ha.

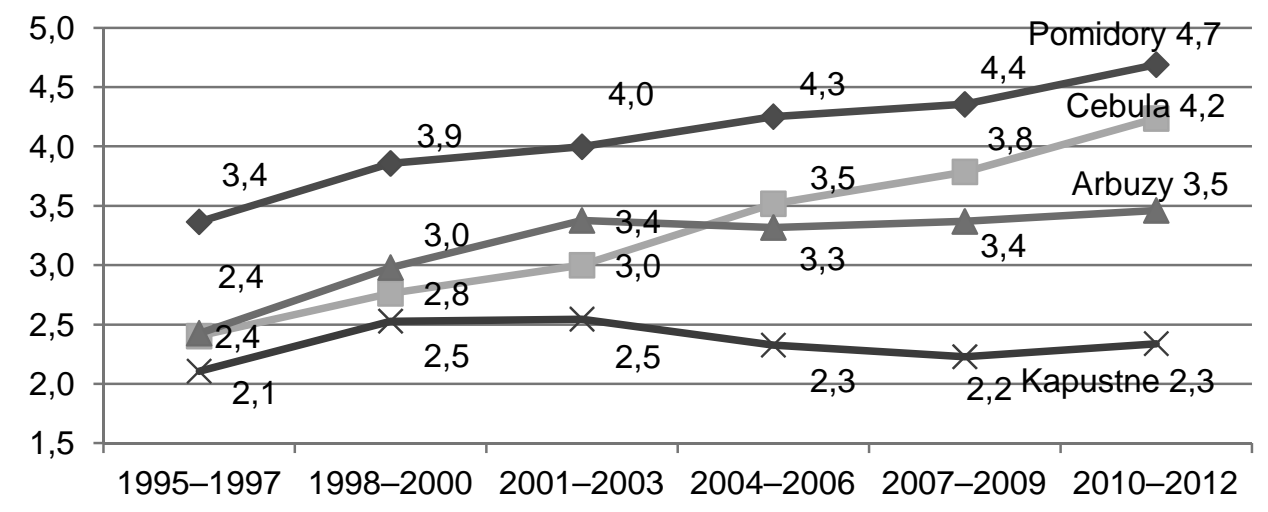

\section{Rysunek 1}

Powierzchnia zasiewów trzech głównych warzyw w latach 1995-2012 [mln. ha]

Źródło: Opracowanie własne na podstawie danych FAOSTAT.

W latach 1995-1997 cebula stanowiła średnio 6,2\% powierzchni warzyw. Powierzchnią uprawy ustępowała jedynie uprawom pomidorów $(8,6 \%)$. W latach 2010-2012 udział cebuli w powierzchni warzyw wzrósł do 7,5\%, co oznacza, że tempo wzrostu uprawy tego warzywa rosło szybciej niż pomidorów i arbuzów. Wśród głównych warzyw najwolniej wzrastała powierzchnia uprawy kapustnych (44\%), co doprowadziło do spadku ich udziału w zasiewach warzyw do 4,1\% w latach 2010-2012 wobec 5,4\% w latach 1995-1997. Średnio 8\% produkcji cebuli podlega wymianie międzynarodowej. W latach 2010-2012 eksport wyniósł 7,1 mln ton i był 2,3-krotnie wyższy od tego z lat 1995-1997. 


\section{Główni producenci oraz eksporterzy i importerzy cebuli}

Największym producentem cebuli są Chiny (tab. 1). Dynamika chińskich zbiorów przewyższała światowe tempo wzrostu produkcji cebuli. W latach 2000 -2012 produkcja Chin była 2,4-krotnie wyższa od tej z lat 1995-1997 i wyniosła $22,2 \mathrm{mln}$ ton. Udział w światowej produkcji zwiększył się z 23\% w latach 1995-1997 do 27\% w latach 2010-2012. Głównym czynnikiem zwiększającym produkcję była powierzchnia zasiewów. W latach 1995-2012 Chiny zwiększały ją rokrocznie o kilka procent (wyjątkiem był rok 2008, kiedy powierzchnia uprawy spadła względem roku wcześniejszego o 7\%).W latach 2010-2012 powierzchnia uprawy w tym kraju wynosiła $1 \mathrm{mln}$ ha i była 2,3-krotnie wyższa od przeciętnej z lat 1995-1997. Jeszcze szybciej rosły zbiory drugiego producenta - Indii. W analizowanym okresie produkcja w tym kraju zwiększyła się 4,3-krotnie - do $16 \mathrm{mln}$ ton. Wynikiem tego był 2-krotny wzrost udziału Indii w wielkości światowych zbiorów, który w latach 2010-2012 osiągnął 20\%. W Indiach w latach 2010-2012 powierzchnia uprawy cebuli zwiększyła się 2,7-krotnie - do $1 \mathrm{mln}$ ha. Plony cebuli zwiększyły się o 57\%. Powierzchnia uprawy cebuli w Indiach w stosunku rok do roku wahała się znacznie bardziej niż w Chinach. Po latach wysokich cen, powodowanych mniejszą podaża, gwałtownie wzrosła powierzchnia zasiewów. W Indiach warzywo to jest produktem pierwszej potrzeby. Jest stosowana powszechnie do większości dań. W latach mniejszych urodzajów

Tabela 1

Najwięksi producenci cebuli w latach 1995-1997 i 2010-2012

\begin{tabular}{|l|c|c|c|c|c|c|c|c|}
\hline $\begin{array}{l}\text { Wyszcze- } \\
\text { gólnienie }\end{array}$ & \multicolumn{4}{|c|}{$1995-1997$} & \multicolumn{5}{|c|}{$2010-2012$} \\
\hline Państwo & [mln ton] & {$[\%]$} & {$[$ [tys. ha] } & {$[\mathrm{dt} / \mathrm{ha}]$} & {$[\mathrm{mln}$ ton] } & {$[\%]$} & [tys. ha] & [dt/ha] \\
\hline Świat & 40 & 100 & 2402 & 167 & 82 & 100 & 4236 & 194 \\
\hline Chiny & 9,3 & 23,1 & 437 & 213 & 22,2 & 26,9 & 1006 & 220 \\
\hline Indie & 3,8 & 9,5 & 381 & 100 & 16,3 & 19,8 & 1037 & 157 \\
\hline USA & 3,0 & 7,5 & 67 & 445 & 3,3 & 4,0 & 60 & 554 \\
\hline Egipt & 0,4 & 1,0 & 17 & 238 & 2,2 & 2,6 & 62 & 353 \\
\hline Iran & 1,2 & 2,9 & 45 & 257 & 2,1 & 2,6 & 63 & 337 \\
\hline Turcja & 2,3 & 5,7 & 115 & 198 & 2,0 & 2,4 & 67 & 293 \\
\hline Rosja & 1,0 & 2,5 & 94 & 108 & 1,9 & 2,3 & 92 & 208 \\
\hline Pakistan & 1,1 & 2,7 & 78 & 139 & 1,8 & 2,2 & 134 & 133 \\
\hline Brazylia & 0,9 & 2,3 & 71 & 128 & 1,6 & 1,9 & 65 & 246 \\
\hline Holandia & 0,6 & 1,4 & 11 & 494 & 1,4 & 1,7 & 29 & 488 \\
\hline
\end{tabular}

Źródło: Opracowanie własne na podstawie danych FAOSTAT. 


\section{6}

i wzrostu cen dochodziło w tym kraju (jak w 2010 roku) do tzw. kryzysów cebulowych, podczas których władze centralne wprowadzały restrykcje w handlu tym warzywem [The Hindu 2010].

Wśród dziesięciu największych producentów najszybciej rosły zbiory w Egipcie. W latach 2010-2012 zbiory w tym kraju wynosily 2,2 mln. ton i były 5,3-krotnie wyższe od średniego poziomu z lat 1995-1997. W Rosji, Iranie, Brazylii oraz Pakistanie produkcja wzrosła od 90 do 65\%. Z krajów Unii Europejskiej w gronie największych producentów znalazła się tylko Holandia, której produkcja w latach 2010-2012 wzrosła względem lat 1995-1997 2,5-krotnie (do 1,4 mln USD). Tureckie zbiory cebuli uległy obniżeniu o $14 \%$ względem lat 1995-1997 - do niespełna $2 \mathrm{mln}$ ton w latach 2010-2012. Wśród pozostałych liczących się producentów zwrócić należy uwagę na Sudan, Bangladesz oraz Birmę. W państwach tych szybko rosły zbiory, osiagając w latach 2010-2012 $1,1 \mathrm{mln}$ ton. Sudan zwiększył produkcję blisko 20-krotnie, Bangladesz 7,2-krotnie, a Birma 6-krotnie. Państwa te w najbliższych latach znajdą się wyżej w czołówce światowych producentów, jednak nie będą w stanie zagrozić liderom produkcji. W latach 1995-2012 znaczący wzrost wydajności produkcji miał miejsce w Rosji i Brazylii, gdzie plony w latach 2010-2012 były o 90\% wyższe niż w latach 1995-1997. Plony w tych krajach sąjednak nadal niższe od notowanych w USA czy Japonii, gdzie sięgają 400-550 dt/ha.

Zbiory w Polsce, w stosunku do lat 1995-1997, zmniejszyły się o 6\% (do 632 tys. ton w latach 2010-2012), a udział Polski w światowej produkcji obniżył się z 1,7\% w latach $1995-2000$ do $0,8 \%$.

Największymi eksporterami cebuli są Holandia, Indie oraz Chiny (tab. 2). Holandia w latach 2004-2006 oraz 2007-2009 przejściowo utraciła pozycję głównego eksportera na rzecz Indii. Indie eksportują znaczne ilości cebuli w latach urodzaju powodującego nadwyżkę na rynku wewnętrznym. W badanym okresie w grupie trzech największych eksporterów sprzedaż zagraniczna najszybciej, bo 11,5-krotnie, wzrosła w stosunku do początku okresu w Chinach, osiagając w latach 2010-2012 1,3 mln ton. Wzrost indyjskiego oraz holenderskiego eksportu był wolniejszy, bo 3,5- oraz 3-krotny. W Indiach wskaźnik orientacji eksportowej (udział eksportu w produkcji) wahał się w badanym okresie od 5,5 do 11,5\%. W Chinach wskaźnik ten systematycznie rósł, jednak mimo niemal 5-krotnego wzrostu w stosunku do lat 1995-1997 nadal pozostał niski, gdyż w latach 2010-2012 osiaggnął zaledwie 3\%. Chiny były w tym okresie dużym producentem, ale jednocześnie konsumentem własnej produkcji i tylko niewielki odsetek podaży lokowały na rynkach zagranicznych. Wskaźnik orientacji eksportowej Holandii był bardzo wysoki przez cały okres (powyżej 75\%), a w latach 2010-2012 przekroczył o 11\% wielkość średniej produkcji cebuli w tym kraju. Świadczy to o rozmiarach reeksportu cebuli realizowanego przez 
Tabela 2

Główni eksporterzy cebuli w świecie w latach 1995-1997, 2004-2006, 2010-2012 [tys. ton]

\begin{tabular}{|l|c|c|c|c|c|c|c|}
\hline Wyszczególnienie & $1995-1997$ & {$[\%]$} & $2004-2006$ & {$[\%]$} & $2010-2012$ & {$[\%]$} & Dynamika \\
\hline Razem & 3126 & 100 & 5590 & 100 & 7094 & 100 & 227 \\
\hline Holandia & 501 & 16 & 900 & 16 & 1556 & 22 & 311 \\
\hline Indie & 371 & 12 & 1075 & 19 & 1293 & 18 & 349 \\
\hline Chiny & 59 & 2 & 520 & 9 & 669 & 9 & 1143 \\
\hline Egipt & 108 & 3 & 278 & 5 & 440 & 6 & 408 \\
\hline Meksyk & 260 & 8 & 273 & 5 & 357 & 5 & 138 \\
\hline USA & 286 & 9 & 319 & 6 & 350 & 5 & 122 \\
\hline Hiszpania & 249 & 8 & 240 & 4 & 243 & 3 & 98 \\
\hline Argentyna & 239 & 8 & 224 & 4 & 202 & 3 & 84 \\
\hline Peru & 12 & 0 & 55 & 1 & 169 & 2 & 1408 \\
\hline Nowa Zelandia & 146 & 5 & 168 & 3 & 163 & 2 & 111 \\
\hline
\end{tabular}

Źródło: Opracowanie własne na podstawie danych FAOSTAT oraz CIHZ i CAAC

ten kraj. Holandia kupuje cebulę głównie w krajach europejskich i sprzedaje ją do innych państw [Nosecka 2012].

Udział Holandii, Indii oraz Chin w eksporcie światowym wzrósł z 30\% w latach 1995-1997 do 51\% w latach 2010-2012, a w wartości z 24 do $43 \%$. Spośród pozostałych krajów należących do grupy 10 największych eksporterów cebuli najbardziej wzrósł eksport z Peru (14-krotnie), jednak wielkość sprzedaży zagranicznej w latach 2010-2012 nie przekroczyła 170 tys. ton. Wzrastała również (ale wolniej, bo 4-krotnie) sprzedaż z Egiptu, a jej wielkość wyniosła 440 tys. ton i ustępowała tylko Holandii, Indiom oraz Chinom. Wzrost wolumenu eksportu w latach 2010-2012 w porównaniu z latami 1995-1997 był wolniejszy w Meksyku oraz USA (38 i 22\%), a spadał w Argentynie (16\%) oraz Hiszpanii (2\%). Wskaźnik orientacji eksportowej w pozostałych krajach należących do 10 największych eksporterów w latach 2010-2012 był wysoki w Argentynie (28\%), Meksyku (27\%), Peru (23\%) oraz Egipcie i Hiszpanii (20\%). Udział eksportu w produkcji względem lat 1995-1997 wzrastał dynamicznie w Peru (4,5-krotnie), a malał w Argentynie, która na początku okresu lokowała na rynkach zagranicznych około połowy produkcji. Dynamiczny wzrost peruwiańskiej produkcji skutkował wzrostem znaczenia tego kraju w handlu cebulą. Przyczyną spadku znaczenia Argentyny był wolniejszy niż średni światowy wzrost produkcji, która zagospodarowywana była w większej części na rynku wewnętrznym. W USA wskaźnik orientacji eksportowej był stabilny i utrzymywał się na poziomie około $10 \%$.

W Polsce - 14. eksporterze w świecie - sprzedaż zagraniczna zwiększyła się o $37 \%$ - do 119 tys. ton w latach 2010-2012. 
Z krajów europejskich w eksporcie liczyły się jeszcze Francja oraz Niemcy. Niemiecki eksport wzrósł w stosunku do lat 1995-1997 aż 3,7-krotnie i osiągnął w latach 2010-2012 85 tys. ton. Sprzedaż z Francji rosła wolniej (56\%), ale jej wolumen był wyższy i wyniósł w latach 2010-2012 106 tys. ton.

Średnie ceny eksportowe wzrosły w stosunku do lat 1995-1997 o 32\% i osiagnęeły w latach 2010-2012 0,41 USD/kg (tab. 3). Wśród największych eksporterów najniższe ceny sprzedaży zagranicznej wystąiły w Indiach. Chińskie ceny przewyższały indyjskie (od 1 do 45\%). Najdroższą cebulę oferowała Holandia, jednak średnia cena sprzedaży z tego kraju w stosunku do lat 1995-1997 wzrosła najmniej w grupie głównych eksporterów, bo zaledwie o $20 \%$, podczas gdy ceny indyjskiego warzywa wzrosły o 64 , a chińskiego o $88 \%$. Polskie ceny eksportowe wzrosły w ostatnich latach, przewyższając w latach 2007-2009 i 2010-2012 średnią światową cenę eksportową. W stosunku do lat 1995-1997 ceny eksportowanej z Polski cebuli wzrosły aż 2,5-krotnie. Wśród liczących się eksporterów z Europy droższą cebulą miały Niemcy oraz Francja. Analizując ceny należy pamiętać, iż w strukturze eksportu cebuli z niektórych państw (np. Francja) istotną rolę odgrywa cebula biała (czosnkowa), czerwona oraz szalotka, których ceny są wyższe.

Tabela 3

Średnie ceny eksportowe cebuli w wybranych państwach w latach 1995-1997, 1998-2000, 2001-2003, 2004-2006, 2007-2009, 2010-2012 [USD/kg]

\begin{tabular}{|l|c|c|c|c|c|c|}
\hline $\begin{array}{l}\text { Wyszcze- } \\
\text { gólnienie }\end{array}$ & 1995-1997 & 1998-2000 & 2001-2003 & 2004-2006 & 2007-2009 & 2010-2012 \\
\hline Średnia & 0,31 & 0,27 & 0,25 & 0,29 & 0,38 & 0,41 \\
\hline Indie & 0,18 & 0,18 & 0,16 & 0,17 & 0,25 & 0,29 \\
\hline Holandia & 0,31 & 0,26 & 0,24 & 0,29 & 0,39 & 0,38 \\
\hline Chiny & 0,22 & 0,23 & 0,19 & 0,23 & 0,25 & 0,42 \\
\hline Polska & 0,18 & 0,15 & 0,15 & 0,27 & 0,49 & 0,45 \\
\hline Niemcy & 0,38 & 0,34 & 0,37 & 0,43 & 0,50 & 0,53 \\
\hline Francja & 0,43 & 0,45 & 0,50 & 0,75 & 1,00 & 0,81 \\
\hline
\end{tabular}

Źródło: Opracowanie własne na podstawie danych UN Comtrade.

Głównymi importerami cebuli są: Malezja, Rosja, USA, Japonia, Wielka Brytania oraz Arabia Saudyjska (tab. 4). Największym importerem jest Malezja. W latach 2010-2012 kraj ten zwiększył przywóz względem lat 1995-1997 2,4-krotnie, wyprzedzając dotychczasowego największego importera - Rosję. Dynamicznie wzrastał również import Indonezji (3,6-krotnie), Arabii Saudyjskiej (2,6-krotnie) oraz Holandii (2,4-krotnie). Państwa te zwiększyły swój udział w wolumenie światowego importu. W Rosji, USA, Japonii, Wielkiej Brytanii 
Tabela 4

Czołowi importerzy cebuli w świecie [tys. ton]

\begin{tabular}{|l|c|c|c|c|c|c|c|}
\hline Wyszczególnienie & $1995-1997$ & {$[\%]$} & $2007-2009$ & {$[\%]$} & $2010-2012$ & {$[\%]$} & Dynamika \\
\hline Malezja & 193 & 7 & 422 & 8 & 454 & 8 & 235 \\
\hline Rosja & 233 & 8 & 483 & 9 & 395 & 7 & 170 \\
\hline USA & 253 & 9 & 402 & 7 & 390 & 7 & 155 \\
\hline Japonia & 202 & 7 & 207 & 4 & 352 & 6 & 174 \\
\hline Wielka Brytania & 218 & 8 & 373 & 7 & 352 & 6 & 161 \\
\hline Arabia Saudyjska & 124 & 4 & 224 & 4 & 315 & 6 & 255 \\
\hline Niemcy & 305 & 11 & 235 & 4 & 242 & 4 & 79 \\
\hline Brazylia & 135 & 5 & 179 & 3 & 204 & 4 & 152 \\
\hline Holandia & 82 & 3 & 129 & 2 & 192 & 3 & 235 \\
\hline Indonezja & 48 & 2 & 134 & 2 & 172 & 3 & 358 \\
\hline
\end{tabular}

Źródło: Opracowanie własne na podstawie danych UN Comtrade.

oraz Brazylii rósł import względem średniego z lat 1995-1997, ale wolniej bo o 55-70\%, co spowodowało obniżenie udziału tych krajów w wolumenie światowego przywozu. Niemcy, jako jedyny kraj w grupie głównych importerów, zmniejszyły przywóz cebuli o 21\% względem lat 1995-1997, co spowodowało obniżenie o 7 p.p. udziału tego kraju w strukturze importu do zaledwie $4 \%$ w latach 2010-2012.

\section{Produkcja i handel w Polsce}

Produkcja warzyw podstawowych w Polsce w latach 1995-2012 charakteryzowała się tendencją spadkowa (rys. 2). Łączne zbiory warzyw gruntowych obniżyły się względem lat 1995-1997 o 14\%, osiągając w latach 2010-2012 4,5 mln ton. Najbardziej spadły zbiory kapusty (39\%) oraz buraków ćwikłowych (33\%), a także ogórków (21\%) i pomidorów (11\%). Wzrosły nieznacznie jedynie zbiory marchwi (3\%).

Zbiory cebuli w badanym okresie charakteryzowały się dużą zmiennością. Wynikała ona głównie z różnic w plonowaniu, gdyż średnie roczne zasiewy cebuli do lat 2007-2009 były względnie stałe i wynosiły 34-35 tys. ha. Cebula jest szczególnie wrażliwa na niedobory wody ze względu na płytki system korzeniowy. W ostatnich latach (2010-2012) zbiory obniżyły się względem początku okresu o 6\%, co wynikało przede wszystkim ze spadku powierzchni upraw w następstwie zmniejszania się zapotrzebowania na polską cebulę na rynku krajowym oraz na rynkach zagranicznych. Powierzchnia upraw w latach 2010-2012 spadła w stosunku do lat 1995-1997 o 26\% - do 25 tys. ha. 


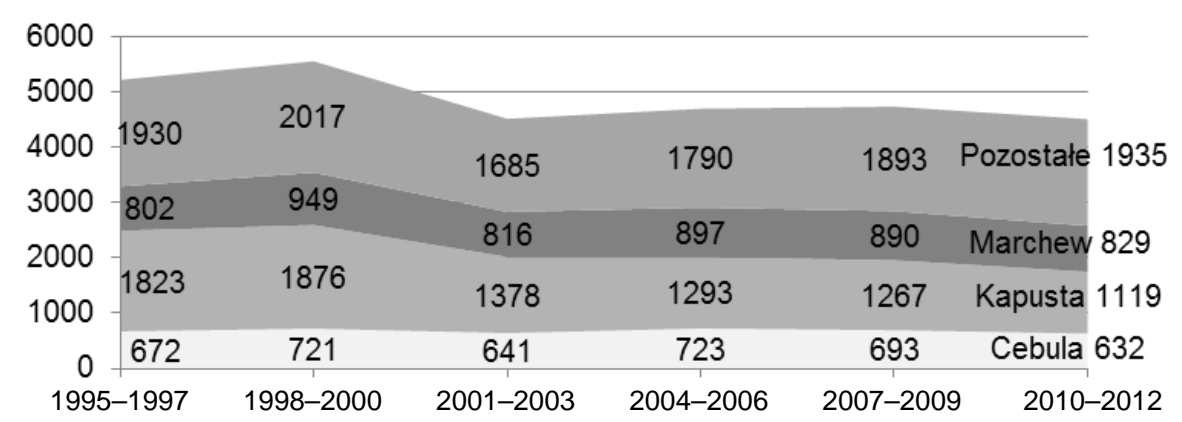

\section{Rysunek 2}

Zbiory warzyw w Polsce w latach 1995-2012 [tys. ton]

Źródło: Opracowanie własne na podstawie danych GUS.

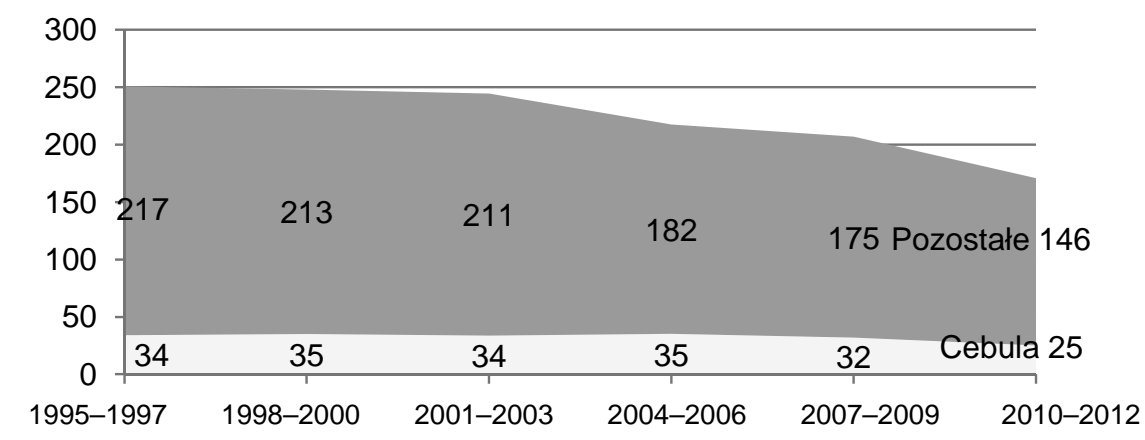

\section{Rysunek 3}

Powierzchnia uprawy warzyw gruntowych w Polsce w latach 1995-2012 [tys. ha] Źródło: Opracowanie własne na podstawie danych GUS.

Rejony uprawy cebuli w Polsce związane są z występowaniem dogodnych warunków naturalnych. Cebula pod względem warunków glebowych jest warzywem wymagającym. Preferuje żyzne, bogate w próchnicę, przepuszczalne, ale o wysokiej pojemności wodnej gleby. Nie może być uprawiana na glebach zwięzłych oraz bardzo lekkich. Wymaga również wysokiej kultury rolnej i intensywności produkcji. Głównymi rejonami uprawy w Polsce są obszary o intensywnym rolnictwie i urodzajnych glebach. Liderem w zasiewach cebuli jest województwo wielkopolskie. W latach 2010-2012 w tym województwie zlokalizowanych było $25 \%$ upraw. Niewiele mniej cebuli uprawiono w województwie kujawsko-pomorskim (20\%). Udział tych dwóch województw w strukturze uprawy cebuli wzrastał kosztem województw mazowieckiego oraz łódzkiego. Małe znaczenie w produkcji cebuli mają województwa warmińsko-mazurskie, śląskie, podlaskie, pomorskie, zachodniopomorskie, opolskie oraz lubuskie, w których powierzchnia zasiewów w ostatnich latach nie przekroczyła 1 tys. ha. Plony cebuli w Polsce w latach 1995-2012, poza rokiem 2006, były wyższe 
od średnich światowych i wykazywały tendencję wzrostową (rys. 4). Średnie polskie polony w latach 2010-2012 były wyższe od tych z lat 1995-1997 o 27\% i wynosiły $251 \mathrm{dt} / \mathrm{ha}$. Dynamika krajowej wydajności przewyższała światową o 10 p.p. Plony osiagane w Polsce były jednak znacznie niższe w porównaniu do wydajności w Niemczech, gdzie w analizowanym okresie wynosiły od $384 \mathrm{dt} / \mathrm{ha}$ w latach 1995-1997 do 496 dt/ha w latach 2010-2012. Plony w Polsce były wyższe od notowanych w Indiach (około 50\% w latach 2010-2012), a porównywalne z chińskimi.

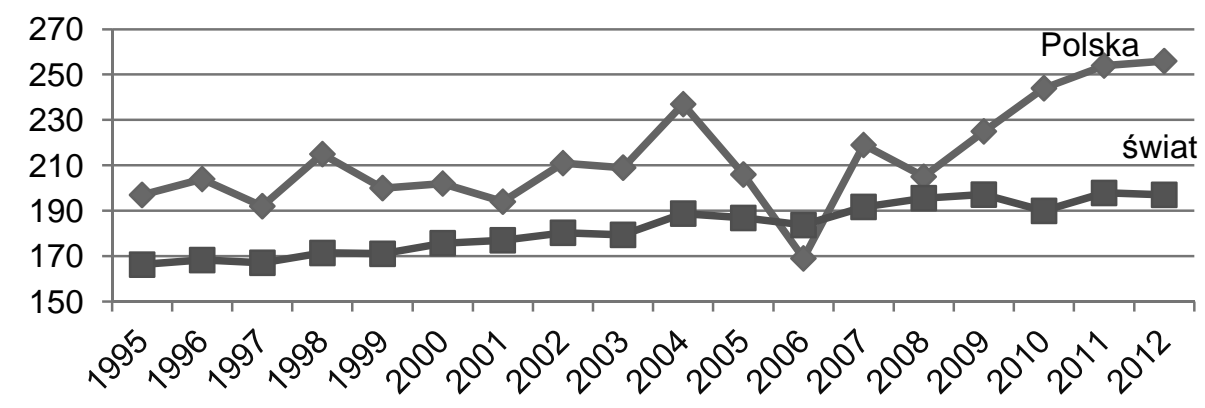

\section{Rysunek 4}

Plony cebuli w Polsce i na świecie w latach 1995-2011 [dt/ha]

Źródło: Opracowanie własne na podstawie danych GUS oraz FAOSTAT.

W latach 2010-2012 2,5-krotnie wzrósł eksport z Polski warzyw świeżych. W latach 1995-1997 Polska eksportowała średnio 151 tys. ton, a w latach 2010-2012 już 369 tys. ton. Udział cebuli we wzrastającym eksporcie warzyw systematycznie malał - z 58\% w latach 1995-1997 do 32\% w latach 20010-2012.

Eksport cebuli z Polski w latach 2010-2012 wynosił 119 tys. ton i przekraczał poziom z lat 1995-1997 o 37\% (rys. 5). Od lat 2004-2006 następował systematyczny spadek eksportu, powodowany wzrostem znaczenia w handlu światowym państw półkuli południowej. Najważniejszym partnerem handlowym Polski były państwa tzw. starej Unii Europejskiej. W latach 1995-1997 udział sprzedaży do UE-15 wynosił 58\% wolumenu, a w latach 2010-2012 69\%. Największe znacznie w eksporcie do UE-15 odgrywa Holandia, Wielka Brytania oraz Niemcy. Do krajów tych w badanym okresie trafiło średnio od 80 do $86 \%$ wolumenu eksportu cebuli świeżej przeznaczonego do UE-15. W strukturze eksportu do UE-15 wzrastało znaczenie Wielkiej Brytanii. W latach 2010-2012 do kraju tego trafiło 31 tys. ton wobec 5,3 tys. ton w latach 1995-1997. Eksport do Holandii wahał się w granicach 25-34 tys. ton, ale jego udział w wolumenie eksportu do UE-15 spadł z 50\% w latach 1995-1997 do 34\% w latach 2010-2012. Obniżył się również udział sprzedaży do Niemiec z 24 do $11 \%$ w latach 2010-2012. Ceny uzyskiwane za sprzedaż do UE-15 były najwyższe i wyniosły 
w latach 2010-2012 0,55 USD/kg. Drugą grupę odbiorców polskiej cebuli stanowiły państwa nowoprzyjęte do UE. Największymi odbiorcami polskiej cebuli z grupy krajów UE-12 były Rumunia oraz Republika Czeska. Mniejsze znaczenie miał eksport na Litwę i do Łotwy. Do tych państw trafiło blisko 70\% eksportu przeznaczonego do UE-12. Ceny uzyskiwanie w eksporcie do UE-12 były niższe od cen sprzedaży do UE-15 i stanowiły od 38 do $52 \%$ średnich cen sprzedaży do UE-15.

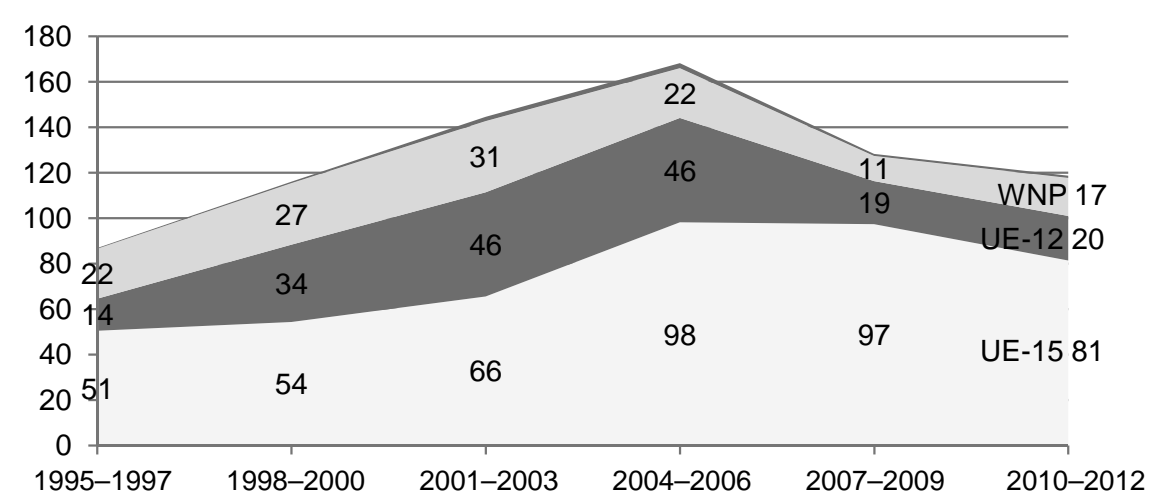

\section{Rysunek 5}

Eksport cebuli z Polski w latach 1995-2012 [tys. ton]

Źródło: Opracowanie własne na podstawie danych ClHZ i CAAC.

Udział eksportu do państw Wspólnoty Niepodległych Państw obniżył się z 25\% polskiej sprzedaży zagranicznej cebuli w latach 1995-1997 do 14\% w latach 2010-2012. Największe znaczenie w eksporcie do krajów WNE miała Rosja, Białoruś oraz Ukraina. Na początku okresu większość eksportu trafiało do Rosji (59\% w latach 1995-1997) oraz Białorusi (35\%), ale ich znaczenie zmalało na rzecz Ukrainy, do której w latach 2010-2012 trafiło 54\% wolumenu polskiego eksportu cebuli przeznaczonego do WNP. Średnie ceny w sprzedaży cebuli do WNP były niższe niż do UE-15 i stanowiły od 31 do $75 \%$ średnich cen sprzedaży do UE-15.

Polska jest również importerem cebuli. Import w latach 2010-2012 wyniósł 85 tys. ton, co oznacza 3,2-krotny wzrost w porównaniu ze średnią z lat 1995-1997. Ponad 92\% importu pochodziło z krajów UE-15. Głównym dostawca cebuli była Holandia. Z tego państwa sprowadzano od 72 do $86 \%$ całkowitego importu tego warzywa. Mniejsze znaczenie w imporcie miały Niemcy. Średnie ceny cebuli sprowadzanej z UE były niższe od cen w eksporcie tego warzywa z Polski. Importowana cebula w bardzo dużym stopniu wykorzystywana była w krajowych zakładach przetwórczych. 
Polska przez cały analizowany okres była eksporterem netto cebuli, jednak w wyniku rosnącego znaczenia importu, eksport netto wykazywał tendencję spadkową (rys. 6).

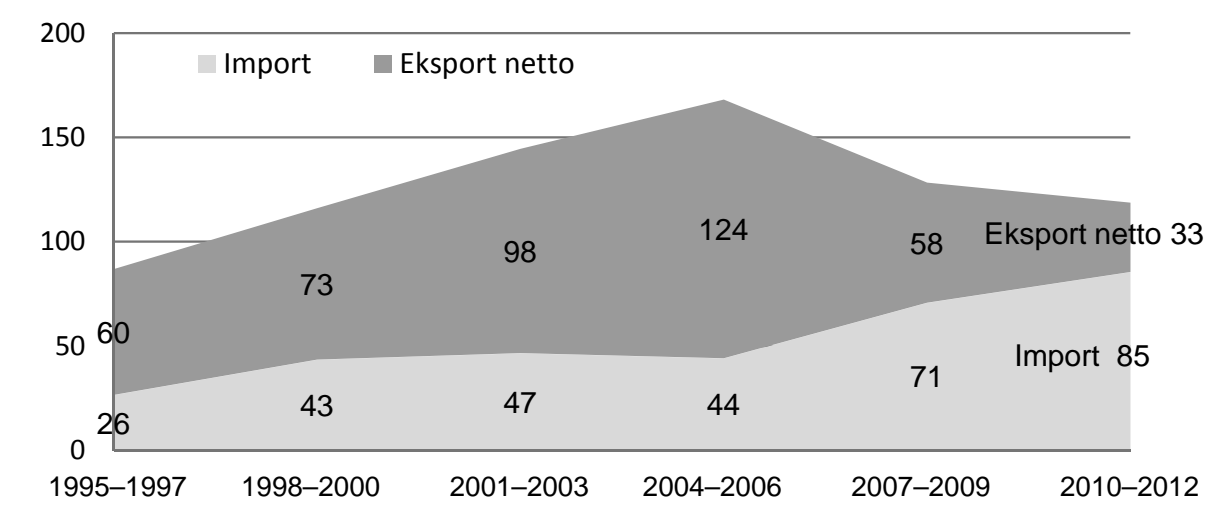

Rysunek 6

Export netto i import cebuli w Polsce w latach 1995-2011 [tys. ton]

Źródło: Opracowanie własne na podstawie danych $\mathrm{CIHZ}$ i CAAC.

Pogorszenie wyników w polskim handlu zagranicznym cebulą jest wynikiem wyraźniej utraty przez nasz kraj konkurencyjności na światowym rynku warzyw.

\section{Podsumowanie}

1. Średnie światowe zbiory cebuli wzrosły dwukrotnie w stosunku do średnich zbiorów z lat 1995-1997, osiagając w latach 2010-2012 $82 \mathrm{mln}$ ton.

2. Największym producentem cebuli na świecie są Chiny, których produkcja wzrosła z 9,3 mln ton w latach 1995-1997 do 22,2 mln ton w latach 2010-2012. Udział tego kraju w światowej produkcji zwiększył się z 23\% w latach 1995-1997 do 27\% w latach 2010-2012. Drugim dużym producentem są Indie, których udział w światowej produkcji wzrósł dwukrotnie i osiągnął w latach 2010-2012 20\% światowych zbiorów.

3. Najwięksi eksporterzy to Holandia, Indie oraz Chiny. Udział tych państw w światowym eksporcie wzrósł z 30\% w latach 1995-1997 do 59\% w latach 2010-2012. Oznacza to postępującą dominację tych krajów w światowym eksporcie.

4. Udział Polski w światowych zbiorach i eksporcie cebuli zmniejsza się i średnio w latach 2010-2012 wyniósł odpowiednio 0,8 i 1,6\% wobec 1,7 i 2,8\% w latach 1995-1997. Wynikało to przede wszystkim z powol- 
nej utraty przez Polską konkurencyjności cenowej w porównaniu z innymi liczącymi się eksporterami, zwłaszcza Chinami i Indiami. Przywrócenie tendencji wzrostowej wymaga zatem przede wszystkim obniżenia cen w polskiej ofercie eksportowej przy równoczesnej poprawie systemu organizacji sprzedaży na rynku zagranicznym.

\section{Literatura}

Centrum analityczne administracji centralnej i centrum informatyki i handlu zagranicznego [dane niepublikowane] 1995-2011.

FAOSTAT, http://faostat.fao.org/ (data dostępu: 10.10.2013).

GUS, Wyniki produkcji roślinnej za lata 1996-2012.

NOSECKA B., 2012: Sytuacja na rynku wybranych produktów ogrodniczych i jej wplyw na polski rynek ogrodniczy, Instytut Ekonomiki Rolnictwa i Gospodarski Żywnościowej - Państwowy Instytut Badawczy, Warszawa.

MIERWIŃSKI J., 2003: Rynek cebuli - stan obecny i perspektywy, Hasło Ogrodnicze, nr 12, s. 32-34.

Roczniki Statystyczne Rolnictwa I Obszarów Wiejskich, GUS z lat 1992, 1998, 2004, 2006-2012 .

The Hindu: The political price of onion, www.thehindu.com (data dostępu: 18.02.2014).

Un Comtrade, http://comtrade.un.org/ (data dostępu: 10.10.2013).

\section{Changes on the onion market in 1995-2012}

\section{Abstract}

The article presents changes on the onion market in the years 1995-2012. It shows production data which contain the level of harvest, yields, and sown area in the world and in Poland. The article analyses the main tendencies in international trade, taking into account the biggest exporters and importers and value and directions of onion foreign trade in Poland. 